\title{
REPRODUCTIVE DISORDERS CAUSED BY Toxoplasma gondii IN SHEEP
}

\author{
Angélica Consalter ${ }^{1}$ \\ Andressa Ferreira da Silva ${ }^{2}$ \\ Adriana Costa da Motta ${ }^{3}$ \\ Ana Maria Reis Ferreira ${ }^{1}$
}

CONSAlTER, A; SILVA, A. F. da; MOTTA, A. C. da; FERREIRA, A. M. R. Reproductive disorders caused by Toxoplasma gondii in sheep. Arq. Ciênc. Vet. Zool. UNIPAR, Umuarama, v. 19, n. 2, p. 125-130, abr./jun. 2016.

\begin{abstract}
Toxoplasma gondii is a cosmopolitan, intracellular, obligatory parasite protozoan of importance to public and animal health. In sheep, this species is a causative agent of reproductive disorders. The main sign produced by $T$. gondii infection in this species is abortion, which causes economic losses to sheep ranching. The main purpose of this review is to summarize the abortion outbreaks and reproductive disorders caused by $T$. gondii infection in sheep, also addressing aspects of biology, diagnosis, prevention and control of the parasite.
\end{abstract}

KEYWORDS: Abortion. Pathology. Reproduction. Ruminants. Toxoplasmosis.

\section{ALTERAÇÕES REPRODUTIVAS CAUSADAS POR Toxoplasma gondii EM OVINOS}

RESUMO: Toxoplasma gondii é um parasito protozoário intracelular obrigatório cosmopolita de importância para saúde pública e animal. Na espécie ovina é reconhecido como agente causador de distúrbios reprodutivos. O principal quadro clínico causado pela infecção pelo Toxoplasma em ovinos é o abortamento, que causa perdas econômicas. O principal objetivo deste artigo é fazer um levantamento dos surtos de abortamentos e alterações reprodutivas causadas pela infecção por $T$. gondii na espécie ovina, abordando ainda aspectos da biologia, diagnóstico, prevenção e controle do parasito.

PALAVRAS-CHAVE: Aborto. Patologia. Reprodução. Ruminantes. Toxoplasmose.

\section{ALTERACIONES REPRODUCTIVAS CAUSADAS POR Toxoplasma gondii EN OVINOS}

RESUMEN: Toxoplasma gondii es un parásito protozoario intracelular obligatorio cosmopolita, de importancia para la salud pública y animal. En la especie ovina es reconocido como agente causador de trastornos reproductivos. El principal síntoma producido por la infección con Toxoplasma en ovinos es el aborto, lo que provoca pérdidas económicas. Este artículo tiene como objetivo estudiar los brotes de aborto y alteraciones reproductivas causadas por la infección con $T$. gondii en la especie ovina, abordando también aspectos de la biología, diagnóstico, prevención y control del parásito.

PALABRAS CLAVE: Aborto. Patología. Reproducción. Rumiantes. Toxoplasmosis.

\section{Introduction}

Toxoplasma gondii is an obligatory intracellular protozoan of importance to public and animal health (CENCI-GOGA et al., 2013; COSENDEY-KEZENLEITE et al., 2014; SCHLÜTER et al., 2014). Chronic toxoplasma infection affects approximately $30 \%$ of the human population (SCHLÜTER et al., 2014). In sheep, the prevalence rates range from 1.8\% in Northern Tunisia (GHARBI et al., 2013) to 95.7\% in Turkey (MOR; ARSLAN, 2007). The high seroprevalence of $T$. gondii in flocks is a risk factor for the transmission of toxoplasmosis to humans through undercooked meat consumption (BOUGHATTAS et al., 2014; SCHLÜTER et al., 2014).

In sheep and pregnant women, toxoplasma infection can lead to a more severe form of the disease that is congenitally transmitted (HISZCZYŃSKA-SAWICKA et al., 2014; SCHLÜTER et al., 2014).

Sheep with primary infection by $T$. gondii during pregnancy can develop reproductive disorders, such as embryonic resorption, fetal death, mummification, stillbirth, miscarriage or birth-debilitated animals (EDWARDS; DUBEY, 2013; ESTEBAN-REDONDO; INNES, 1997).

Abortion is one of the main signs produced by $T$. gondii infection in sheep and causes economic losses in many countries due to the high prevalence of infection in this species (SILVA et al., 2013a; VAN DEN BROM et al., 2012; VERHELST et al., 2014). The main purpose of this review is to summarize the abortion outbreaks and reproductive disorders that are caused by $T$. gondii infection in sheep, also addressing aspects of the biology, diagnosis, prevention and control of the parasite.

\section{Development}

Life cycle and pathogenesis of Toxoplasma gondii in sheep

Felines are the definitive hosts of $T$. gondii and shed oocysts in feces. Sheep, as most warm-blooded animals, are intermediate hosts in the toxoplasmosis transmission cycle (ESTEBAN-REDONDO; INNES, 1997). Sheep can acquire infection after oral ingestion of sporulated oocysts in the

DOI: https://doi.org/10.25110/arqvet.v19i2.2016.5933

${ }^{1}$ Programa de Pós-Graduação em Clínica e Reprodução Animal, Universidade Federal Fluminense, Niterói, RJ, Brasil. 24230-340, Brazil. Corresponding author: Tel:+5521 26299527 E-mail: angelicaconsalter@hotmail.com

${ }^{2}$ Departamento de Medicina e Cirurgia Veterinária, Universidade Federal Rural do Rio de Janeiro, Seropédica, RJ, Brasil.

${ }^{3}$ Laboratório de Patologia Animal, Universidade de Passo Fundo, Passo Fundo, RS, Brasil. 
environment (soil, contaminated water or food) (DUBEY, 2010; DUBEY; JONES, 2008).

Toxoplasma infection can also occur congenitally when ewes are infected, primarily after the ingestion of oocysts. T. gondii rapidly multiply in the submucosa of the intestine, associated lymph nodes and other organs through the lymph and blood systems (DUBEY, 2010). Upon placental infection with tachyzoites of $T$. gondii, reproductive losses may occur in sheep, such as embryonic resorption, fetal death, mummification, stillbirth and abortion (BUXTON, 1998; EDWARDS; DUBEY, 2013). Abortion in sheep has been reported from 60 to 90 days of gestation, mainly in ewes with primary infection (DUBEY, 2010).

In a recent study of sheep that were experimentally infected with oocysts of $T$. gondii during pregnancy, abortion was reported in the acute phase between seven and 11 days after infection. However, despite the presence of thrombosis and placental infection, the researchers did not detect parasitic DNA. Thus, they suggested that the pathogenesis of abortion in the acute phase may occur as result of vascular damage caused by other mechanisms and not by the parasite replication, as proposed for classic toxoplasmosis (CASTAÑO et al., 2014)

Another form of proven transmission in sheep and goats occurs sexually (LOPES et al., 2013; WANDERLEY et al., 2015). In a study of sheep infected with oocysts and tachyzoites of $T$. gondii after natural mating in seronegative females, there was sexual transmission with subsequent vertical transmission to the lambs (LOPES et al., 2013). After the infection of the intermediate host by $T$. gondii, tissue cysts are formed (most commonly in the brain, liver, heart, muscle) and when ingested by both felines and intermediate hosts, the cycle will continue (DUBEY, 2010). Figure 1 represents the life cycle of $T$. gondii.

Figure 1: Life cycle of Toxoplasma gondii. Reproductive disorders caused by Toxoplasma gondii in sheep

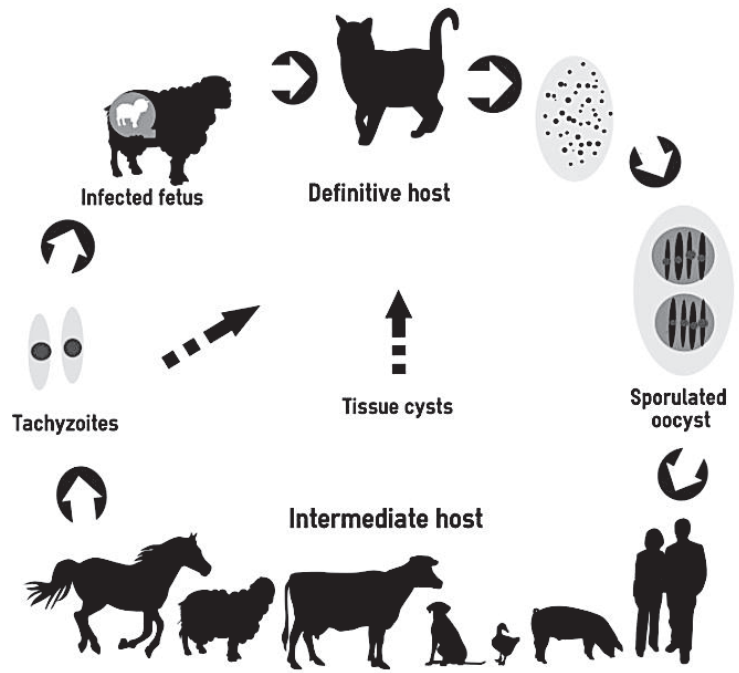

Font: Adapted from Dubey (2010)

\section{Pathological disorders resulting from toxoplasma infec- tion in sheep}

Toxoplasma infection during the pregnancy of female sheep may be associated with necrotic placentitis and infection of the fetus, leading to abortion (BUXTON, 1998; DE MORAES et al., 2011; EDWARDS; DUBEY, 2013; WEISSMANN, 2003). In animals naturally infected by $T$. gondii, abortions and placentitis have occurred (VAN DEN BROM et al., 2012). In a study in which females were infected with oocysts of $T$. gondii during pregnancy, the observed areas exhibited multifocal coagulative necrosis, marked by sharp vascular congestion, thrombosis and infarction in the cotyledons caruncular villi, leading to abortion (CASTAÑO et al., 2014).

In sheep from the State of Pernambuco, Brazil, there were observed placental abortion lesions characterized by non-suppurative inflammatory infiltrate, necrosis and mineralization, suggesting infection by $T$. gondii. The diagnosis was confirmed by detection of parasites in the placenta by nested PCR (DE MORAES et al., 2011).

In the State of Rio Grande do Sul, Brazil, abortions due to natural infection by $T$. gondii occurred in the last month of pregnancy, affecting $58.3 \%$ of the females. Macroscopic examination of a sheep fetus showed changes as heart pallor, marked congestion in the brain and cerebellum (Figure 2), pale foci in the liver, congestion and marbled appearance in the lungs. Microscopy revealed changes suggestive of toxoplasma encephalitis characterized by severe congestion, areas of malacia with cysts, tachyzoites, microgliosis (Figure $3 \mathrm{~A}$ ), fibrinous microthrombosis and lymphocytic meningitis (DA MOTTA et al., 2008).

Figure 2: Brain of an aborted sheep fetus caused by toxoplasmosis infection. Severe congestion and edema in the brain and cerebellum.

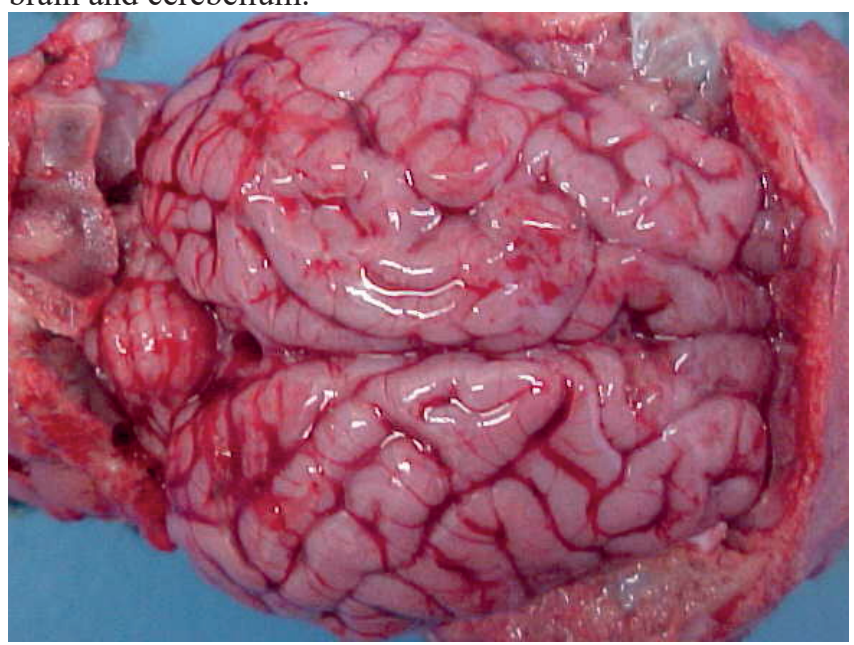

Font: Figure courtesy of Dr. Adriana Costa 
Figure 3: Photomicroscopy of the histopathological analysis of the brain from the same aborted sheep fetus caused by toxoplasmosis infection. A. Toxoplasma encephalitis. Microglial nodules (black arrow). HE 100x. B. Cysts of Toxoplasma gondii (red arrow), immunohistochemistry, 400x.

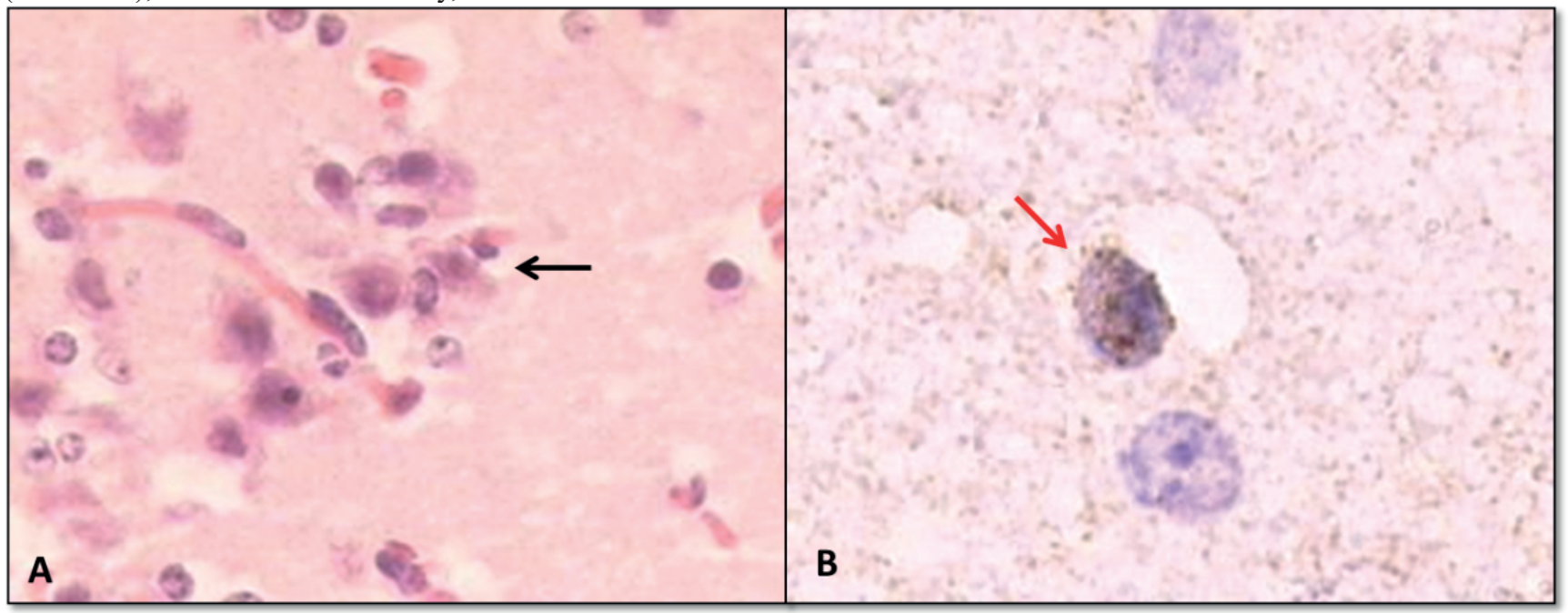

Font: Figure courtesy of Dr. Adriana Costa de Motta, Universidade de Passo Fundo.

Most of the microscopic changes observed in sheep fetuses infected with $T$. gondii are described in brain tissue (ANWAR et al., 2013; DA MOTTA et al., 2008; DUBEY, 2010; O’DONOVAN et al., 2012). Dubey (2010) and O’Donovan et al. (2012), highlight leukoencephalomalacia and gliosis. The areas of malacia are extensive and often observed in the periventricular white matter anterior cerebral region (DUBEY, 2010).

Inflammatory changes characterized by encephalitis, myocarditis and multifocal hepatitis are described in sheep fetuses aborted because toxoplasma infection (DA MOTTA et al., 2008; EDWARDS; DUBEY, 2013; O'DONOVAN et al., 2012; PEREIRA-BUENO et al., 2004a). In addition, tissue cysts and tachyzoites can be observed in the brain tissue of these fetuses, and tachyzoites are often observed adjacently to the cerebral vascular endothelium (ANWAR et al., 2013; DUBEY, 2010; O’DONOVAN et al., 2012). Presence of cysts (Figure $3 \mathrm{~B}$ ) of $T$. gondii in the brain of an aborted sheep fetus was confirmed by immunohistochemistry (IHC) in the State of Rio Grande do Sul (DA MOTTA et al., 2008).
Reproductive losses in sheep by Toxoplasma gondii infection

Reproductive losses in sheep due to infection by $T$. gondii have occurred in different countries. Table 1 shows abortions and stillbirths described in the past 20 years, according to the literature.

In Italy, parasitic DNA was found in 13\% (21/161) of aborted sheep fetuses (CHESSA et al., 2014), and in Netherland, 10.6\% (30/282)of aborted sheep fetuses were positive for $T$. gondii using IHC (VAN DEN BROM et al., 2012). Abortion caused by $T$. gondii has also been described in Spain, affecting 5.4\% (4/74) of fetuses evaluated by PCR, and were observed in $10.8 \%(8 / 74)$ lesions associated with protozoa (MORENO et al., 2012).

In Brazil, abortions in sheep have occurred because of toxoplasmosis infection (DA MOTTA et al., 2008; DE MORAES et al., 2011), but there are few studies to date. In a study by De Moraes et al. (2011) in the State of Pernambuco Brazil, three miscarriages and two stillbirths $14.3 \%(5 / 35)$ caused by $T$. gondii were diagnosed by nested PCR. The agent was detected in all fetal and placental organs of those five animals, with percentages ranging from $100 \%$ in the heart and placenta to $80 \%$ in the spleen, brain, liver and lung, and $60 \%$ in the cerebellum and spinal cord.

Table1: Reports of miscarriages and stillbirths in sheep due to Toxoplasma gondii infection diagnosed by different techniques in the last 20 years.

\begin{tabular}{lccccl}
\hline \multicolumn{1}{c}{ Location } & $\mathbf{N}^{\mathbf{0}}$ & IHCa & PCRb & Fetal Serology & \multicolumn{1}{c}{ Reference } \\
\hline Brazil & 35 & No & $14.3 \%$ & No & (DE MORAES et al., 2011) \\
& 74 & No & $5.4 \%$ & No & (MORENO et al., 2012) \\
\multirow{2}{*}{ Spain } & 53 & No & $16.9 \%$ & $16.9 \%$ & (HURTADO et al., 2001) \\
& 173 & No & $6.9 \%$ & $28.3 \%$ & (PEREIRA-BUENO et al., 2004b) \\
Netherland & 282 & $10.6 \%$ & No & No & (VAN DEN BROM et al., 2012) \\
\multirow{2}{*}{ Iran } & 18 & No & $66 \%$ & No & (HABIBI et al., 2012) \\
& 325 & No & No & $5.2 \%$ & (RAZMI et al., 2010)
\end{tabular}




\begin{tabular}{|c|c|c|c|c|c|}
\hline \multirow{3}{*}{ Italy } & 161 & No & $13 \%$ & No & (CHESSA et al., 2014) \\
\hline & 2421 & No & $11.1 \%$ & No & (MASALA et al., 2003) \\
\hline & 292 & No & $18.1 \%$ & No & (MASALA et al., 2007) \\
\hline Germany & 47 & $10.6 \%$ & $10.6 \%$ & No & (STEUBER, 1995) \\
\hline \multirow{2}{*}{ EUA } & 1.784 & No & No & $10.7 \%$ & (KIRKBRIDE, 1993) \\
\hline & 1.064 & No & No & $20.9 \%$ & (DUBEY; KIRKBRIDE, 1990) \\
\hline Canada & 163 & $19 \%$ & No & No & (HAZLETT et al., 2013) \\
\hline Switzerland & 86 & $19 \%$ & No & No & (CHANTON-GREUTMANN et al., 2002) \\
\hline
\end{tabular}

\section{Diagnosis of $T$. gondii abortion in sheep}

Diagnosis of $T$. gondii can be performed by serological, biological, molecular and histological tests, and also by immunohistochemistry or a combination of these methods (DA MOTTA et al., 2008; DUBEY, 2010).

T. gondii fetal antibodies can be measured using the Modified Agglutination Test (MAT) and Indirect Immunofluorescence Assay (IFA) in sheep fetuses (DUBEY; DESMONTS, 1987). In cases of suspected toxoplasmosis abortion, the placenta and fetus, with special focus on the brain, are sent to the laboratory for the diagnosis of parasitosis (WEISSMANN, 2003). The agent can be isolated from the inoculation placental and fetal tissues in mice (DUBEY, 2010; EDWARDS; DUBEY, 2013; LOPES et al., 2013) Fetal tissue samples (brain, heart, spleen, liver, lung, and spinal cord) and the placenta can be used for molecular diagnosis (DE MORAES et al., 2011).

When associated with pathology and clinical history, IHC allows a definitive diagnosis of toxoplasmosis (DAGLEISH; BENAVIDES; CHIANINI, 2010; DA MOTTA et al., 2008).

According to Silva et al. (2013b), IHC was marked with an anti-T. gondii antibody in liver sections, heart and brain in adult sheep infected with $T$. gondii. In these organs, the marking was found around blood vessels, in some cases on the inside thereof, and in parenchymal cells with a rounded shape. In the same study, the heart was the organ that showed a greater significant difference among the three organs compared with high-titer groups. However, it is noteworthy that in addition to the heart and liver, the brain is an elective organ for the detection of $T$. gondii through the IHC technique (DA MOTTA et al., 2008).

\subsection{Reducing losses: control, prevention and treatment}

Monitoring of toxoplasmosis is an important measure because the disease causes losses to farmers and is a zoonosis (LUCIANO et al., 2011). Laboratory diagnosis, when properly conducted, is efficient, making it a measure of control that should be used to confirm the disease in the herd and thereby reduce the economic impact of infection in the sheep industry (DUBEY, 2010).

The presence of cats is a risk factor for toxoplasmosis transmission in sheep (ANDRADE et al., 2013; COSENDEY-KEZENLEITE et al., 2014). The control of these animals was described as a preventive measure of disease in a US study with pigs, revealing that when cats are removed from direct contact with animals, the chances of infection by
T. gondii decrease (DUBEY et al., 1995).

The therapeutic control of toxoplasmosis is indicated only for abortion outbreaks in which we performed the laboratory diagnosis. In this case, antibiotic administration is recommended as potentiated sulfonamides (sulfa-trimethoprim) and antiparasitics, such as decoquinate and monensin, the latter of which are especially toxic and unpalatable for sheep and goats and can be incorporated into the diet (BUXTON et al., 1996; WEISSMANN, 2003).

It is noteworthy that more important than treatment is the prevention of the disease. Control measures and the prevention of toxoplasmosis are essential for animals and humans. The health management of animals can avoid losses caused by abortion due to the disease (SILVA et al., 2013a).

Therefore, control of cats through spaying and population control, control of rodents in rural environments, proper storage of raw materials and food, improved hygiene for facilities, tools and personnel are simple preventive measures for the control of toxoplasmosis (PAVLOVIC; IVANOVIC 2005).

In addition, the prevention of ovine toxoplasmosis can also be carried out by herd vaccination before the start of the mating period. The first commercial vaccine that was used was a less cystogenic live vaccine (Toxovax ${ }^{\circledR}$, Intervet Shering-Plough), used in France, New Zealand and England to reduce neonatal mortality rates (BUXTON; INNES, 1995).

\section{Conclusions}

T. gondii infection in sheep causes economic losses associated with abortion; in addition, toxoplasmosis is a zoonotic disease. However, the diagnosis of abortion in field-raised animals is difficult because only a few aborted fetuses are subjected to diagnosis, and they are often autolysed. Moreover, in addition to necropsy, it is necessary to perform sequential tests such as IHC to obtain a definitive diagnosis. Finally, this study highlights the need of adequate prevention and early diagnosis for effective control of $T$. gondii infection in sheep to avoid losses by abortion and prevent the transmission of toxoplasmosis to humans.

\section{References}

ANDRADE, M. M. C. et al. Seroprevalence and risk factors associated with ovine toxoplasmosis in Northeast Brazil.

Parasite, v. 20, p. 1-5, 2013.

ANWAR, S. et al. Monitoring of parasitic cysts in the 
brains of a flock of sheep in Egypt. Revista Brasileira de Parasitologia Veterinária, v. 22, n. 3, p. 323-330, 2013.

BOUGHATTAS, S. et al. Survey of the parasite Toxoplasma gondii in human consumed ovine meat in Tunis City. PloS One, v. 9, n. 1, p. e85044, 2014.

BUXTON, D. et al. Decoquinate and the control of experimental ovine toxoplasmosis. The Veterinary Record, v. 138, n. 18, p. 434-436, 1996.

BUXTON, D. Protozoan infections (Toxoplasma gondii, Neospora caninum and Sarcocystis spp.) in sheep and goats: recent advances. Veterinary Research, v. 29, n. 3-4, p. 289$310,1998$.

BUXTON, D.; INNES, E. A. A commercial vaccine for ovine toxoplasmosis. Parasitology, v. 110, Suppl, p. 11-16, 1995.

CASTAÑO, P. et al. Placental thrombosis in acute phase abortions during experimental Toxoplasma gondii infection in sheep. Veterinary Research, v. 45, n. 9, p. 1-12, 2014.

CENCI-GOGA, B. T. et al. Seroprevalence and risk factors for Toxoplasma gondii in sheep in Grosseto district, Tuscany, Italy. BMC Veterinary Research, v. 9, n. 25, p. $1-8,2013$

CHANTON-GREUTMANN, H. et al. Abortion in small ruminants in Switzerland: investigations during two lambing seasons (1996-1998) with special regard to chlamydial abortions. Schweizer Archiv Für Tierheilkunde, v. 144, n. 9, p. 483-492, 2002.

CHESSA, G. et al. Molecular characterization of Toxoplasma gondii Type II in sheep abortion in Sardinia, Italy. Parasite, v. 21, n. 6, p. 1-3, 2014.

COSENDEY-KEZENLEITE, R. I. J. et al. Occurrence and risk factors associated to Toxoplasma gondii infection in sheep from Rio de Janeiro, Brazil. Tropical Animal Health and Production, v. 46, n. 8, p. 1463-1466, 2014.

DAGLEISH, M. P.; BENAVIDES, J.; CHIANINI, F. Immunohistochemical diagnosis of infectious diseases of sheep. Small Ruminant Research, v. 92, n. 1-3, p. 19-35, 2010 .

DA MOTTA, A. C. et al. Ovine abortion associated with toxoplasmosis: serological, anatomo-pathological and immunohistochemistry characterization. Revista Brasileira de Parasitologia Veterinária, v. 17, Suppl 1, p. 204-208, 2008.

DE MORAES, E. P. B. X. et al. Toxoplasma gondii diagnosis in ovine aborted fetuses and stillborns in the State of Pernambuco, Brazil. Veterinary Parasitology, v. 183, n. 1-2, p. 152-155, 2011.

DUBEY, J. P. et al. Sources and reservoirs of Toxoplasma gondii infection on 47 swine farms in Illinois. The Journal of Parasitology, v. 81, n. 5, p. 723-729, 1995.

DUBEY, J. P. Toxoplasmosis of animals and humans second edition. 2. ed. [s.1.]: CRC Press, 2010.

DUBEY, J. P.; DESMONTS, G. Serological responses of equids fed Toxoplasma gondii oocysts. Equine Veterinary Journal, v. 19, n. 4, p. 337-339, 1987.

DUBEY, J. P.; JONES, J. L. Toxoplasma gondii infection in humans and animals in the United States. International Journal for Parasitology, v. 38, n. 11, p. 1257-1278, 2008.

DUBEY, J. P.; KIRKBRIDE, C. A. Toxoplasmosis and other causes of abortions in sheep from north central United States. Journal of the American Veterinary Medical Association, v. 196, n. 2, p. 287-290, 1990.

EDWARDS, J. F.; DUBEY, J. P. Toxoplasma gondii abortion storm in sheep on a Texas farm and isolation of mouse virulent atypical genotype $T$. gondii from an aborted lamb from a chronically infected ewe. Veterinary Parasitology, v. 192, n. 1-3, p. 129-136, 2013.

ESTEBAN-REDONDO, I.; INNES, E. A. Toxoplasma gondii infection in sheep and cattle. Comparative Immunology, Microbiology and Infectious Diseases, v. 20, n. 2, p. 191-196, 1997.

GHARBI, M. et al. Prevalence of Toxoplasma gondii infection in Tunisian sheep. Bulletin De La Société De Pathologie Exotiqu, v. 106, n. 3, p. 184-187, 2013.

HABIBI, G. et al. Detection and Identification of Toxoplasma gondii type one infection in sheep aborted fetuses in Qazvin Province of Iran. Iranian Journal of Parasitology, v. 7, n. 3, p. 64-72, 2012.

HAZLETT, M. J. et al. A prospective study of sheep and goat abortion using real-time polymerase chain reaction and cut point estimation shows Coxiella burnetii and Chlamydophila abortus infection concurrently with other major pathogens. Journal of Veterinary Diagnostic Investigation, v. 25, n. 3, p. 359-368, 2013.

HISZCZYŃSKA-SAWICKA, E. et al. Veterinary vaccines against toxoplasmosis. Parasitology, v. 141, n. 11, p. 13651378, 2014.

HURTADO, A. et al. Single tube nested PCR for the detection of Toxoplasma gondii in fetal tissues from naturally aborted ewes. Veterinary Parasitology, v. 102, n. $1-2$, p. 17-27, 2001.

KIRKBRIDE, C. A. Diagnoses in 1,784 ovine abortions and stillbirths. Journal of Veterinary Diagnostic Investigation, v. 5, n. 3, p. 398-402, 1993.

LOPES, W. D. Z. et al. Sexual transmission of Toxoplasma gondii in sheep. Veterinary Parasitology, v. 195, n. 1-2, p. 
47-56, 2013.

LUCIANO, D. M. et al. Seroepidemiology of toxoplasmosis in goats and sheep from three counties of Rio de Janeiro State, Brazil. Pesquisa Veterinária Brasileira, v. 31, n. 7, p. 569-574, 2011.

MASALA, G. et al. Survey of ovine and caprine toxoplasmosis by IFAT and PCR assays in Sardinia, Italy. Veterinary Parasitology, v. 117, n. 1-2, p. 15-21, 2003.

MASALA, G. et al. Detection of pathogens in ovine and caprine abortion samples from Sardinia, Italy, by PCR. Journal of Veterinary Diagnostic Investigation, v. 19, n. 1, p. 96-98, 2007.

MORENO, B. et al. Occurrence of Neospora caninum and Toxoplasma gondii infections in ovine and caprine abortions. Veterinary Parasitology, v. 187, n. 1-2, p. 312$318,2012$.

MOR, N; ARSLAN, M.O. Seroprevalence of Toxoplasma gondii in sheep in the Kars region. Kafkas Üniversitesi Veteriner Fakültesi Dergisi. v. 13, n. 2, p. 165-170, 2007.

O'DONOVAN, J. et al. Distribution of lesions in fetal brains following experimental infection of pregnant sheep with Toxoplasma gondii. Veterinary Pathology, v. 49, n. 3, p. 462-469, 2012.

PEREIRA-BUENO, J. et al. Evaluation of ovine abortion associated with Toxoplasma gondii in Spain by different diagnostic techniques. Veterinary Parasitology, v. 121, n. $1-2$, p. 33-43, 2004a.

PEREIRA-BUENO, J. et al. Evaluation of ovine abortion associated with Toxoplasma gondii in Spain by different diagnostic techniques. Veterinary Parasitology, v. 121, n. $1-2$, p. 33-43, 2004b.

PAVLOVIC, I.; IVANOVIC S. Toxoplasmosis of goats and its role and importance in pathology of goat production. Biotechnology in Animal Husbandry, v. 21, p. 123-126, 2005.

RAZMI, G. R. et al. A serological study and subsequent isolation of Toxoplasma gondii from aborted ovine fetuses in Mashhad area, Iran. Journal of Parasitology, v. 96, n. 4, p. 812-814, 2010.

SCHLÜTER, D. et al. Animals are key to human toxoplasmosis. International Journal of Medical Microbiology, v. 304, n. 7, p. 917-929, 2014.

SILVA, A. F. et al. Immunohistochemical identification of Toxoplasma gondii in tissues from modified agglutination test positive sheep. Veterinary Parasitology, v. 191, n. 3-4, p. 347-352, 2013a.

SILVA, A. F. da. et al. Toxoplasma gondii in the sheep industry: a global overview and the situation in Brazil.
Revista Brasileira de Ciência Veterinária, v. 20, n. 4, p. 179-188, 2013b.

STEUBER, S. et al. The detection of Toxoplasma gondii in abortion tissues of sheep using the polymerase chain reaction. Deutsche tierärztliche Wochenschrift, v. 102, n. 2, p. 91-93, 1995.

VAN DEN BROM, R. et al. Abortion in small ruminants in the Netherlands between 2006 and 2011. Tijdschrift Voor Diergeneeskunde, v. 137, n. 7, p. 450-457, 2012.

VERHELST, D. et al. Parasite distribution and associated immune response during the acute phase of Toxoplasma gondii infection in sheep. BMC Veterinary Research, v. 10, p. 293, 2014.

WANDERLEY, F. S. et al. Venereal transmission of Toxoplasma gondii in goats after a buck was experimentally infected. Small Ruminant Research, v. 123, n. 2-3, p. 301$305,2015$.

WEISSMANN, J. Presumptive Toxoplasma gondii abortion in a sheep. The Canadian Veterinary Journal, v. 44, n. 4, p. 322-324, 2003. 